\title{
Erratum on: Highly efficient method for gene delivery into mouse dorsal root ganglia neurons
}

\author{
Frontiers Production Office* \\ Frontiers Production Office, Frontiers, Lausanne, Switzerland
}

Keywords: dorsal root ganglion (DRG) neuron, transfection, electroporation, nucleofection, gene expression, primary neurons, EGFP expression, nerve growth factor (NGF)

\section{An erratum on}

Highly efficient method for gene delivery into mouse dorsal root ganglia neurons by Yu, L., Reynaud, F., Falk, J., Spencer, A., Ding, Y.-D., Baumlé, V., et al. (2015). Front. Mol. Neurosci. 8:2. doi: 10.3389/fnmol.2015.00002

Reason for Erratum:

Due to a typesetting error, there was an error in the order of affiliations for authors Chonggang

OPEN ACCESS

Approved by:

Neuroscience Editorial Office,

Frontiers, Switzerland

*Correspondence:

Frontiers Production Office, production.office@frontiersin.org

Received: 07 May 2015 Accepted: 07 May 2015 Published: 18 May 2015

Citation:

Frontiers Production Office (2015) Erratum on: Highly efficient method for gene delivery into mouse dorsal root ganglia neurons.

Front. Mol. Neurosci. 8:16 doi: 10.3389/fnmol.2015.00016
Yuan and Brian B. Rudkin. The affiliations now appearing as Chonggang Yuan ${ }^{1,3 *}$ and Brian B. Rudkin $^{2,3 *}$, should be: Chonggang Yuan ${ }^{2,3 *}$ and Brian B. Rudkin ${ }^{1,3 *}$

1 Differentiation and Cell Cycle Group, Laboratoire de Biologie Moléculaire de la Cellule, UMR 5239, Centre National de la Recherche Scientifique, Ecole normale Supérieure de Lyon, University of Lyon 1 Claude Bernard, University of Lyon, Lyon, France

2 Laboratory of Molecular and Cellular Neurophysiology, East China Normal University, Shanghai, China

3 Joint Laboratory of Neuropathogenesis, Key Laboratory of Brain Functional Genomics, Chinese Ministry of Education, East China Normal University, Centre National de la Recherche Scientifique, Ecole Normale Supérieure de Lyon, Shanghai, China

This error does not change the scientific conclusions of the article in any way. The publisher apologizes for this mistake.

Copyright $(0) 2015$ Frontiers Production Office. This is an open-access article distributed under the terms of the Creative Commons Attribution License (CC BY). The use, distribution or reproduction in other forums is permitted, provided the original author(s) or licensor are credited and that the original publication in this journal is cited, in accordance with accepted academic practice. No use, distribution or reproduction is permitted which does not comply with these terms. 